\title{
Preliminary archaeometric investigation on Middle Neolithic siliceous tools from Limba-Oarda de Jos (Transylvania, Romania)
}

\author{
Mar Rey-Solé ${ }^{1,2}$, Corina Ionescu ${ }^{1,3}$, Marius-Mihai Ciută ${ }^{4}$, \\ Marieta Mureșan-Pop ${ }^{5}$, Viorica Simon ${ }^{6}$
}

1. Babeş-Bolyai University, Department of Geology, Mihail Kogălniceanu 1, 400084, Cluj-Napoca, Romania.

Email: Rey-Solé: mar.reysole@ubbcluj.ro; Ionescu: corina.ionescu@ubbcluj.ro

2. SERP, University of Barcelona, Faculty of Geography and History, Department of History and Archaeology, Section of Prehistory and Archaeology, Barcelona, Spain.

3. Kazan (Volga Region) Federal University, Archeotechnologies \& Archeological Material Sciences Lab., 18 Kremlyovskaya, 420008, Tatarstan, Russia.

4. Lucian Blaga University, Departamentul de Istorie, Patrimoniul şi Teologie Protestantă, Bulevardul Victoriei 10, 550024, Sibiu, Romania. Email: mariusciuta@yahoo.com

5. Babeş-Bolyai University, Nanostructured Materials and Bio-Nano-Interface Center, Interdisciplinary Research Institute on Bio-Nano-Sciences, Treboniu Laurian 42, 400271, Cluj-Napoca, Romania.

Email: Mureșan-Pop: mmuresanpop@gmail.com; Simon: viorica.simon@phys.ubbcluj.ro

\begin{abstract}
:
The present archaeometric study focuses on a set of archaeological siliceous lithic tools that are assigned to the early Vinča culture period (Vinča A and Vinča B1). They were found in several pithouses at Limba-Oarda de Jos (SW Transylvania, Romania), an open settlement that has been dated to 5,405-5,310 cal. BCE, a period in the Middle Neolithic. A total of 322 retouched tools and débitage pieces were typologically and macroscopically investigated. From these, 20 pieces were analysed by polarized light optical microscopy $(\mathrm{OM})$ and 10 pieces were analysed by Fourier-transform infrared spectroscopy (FTIR) in order to identify compositional characteristics, define the petrographic type, and establish the spectral fingerprint of each material.

Four petrographic types were discriminated: radiolarite, chert, fossiliferous chert, and siliceous limestone. Mineralogically, the tools primarily consist of a mass of microquartz and fibrous microquartz (called also 'chalcedony') associated with radiolarians remnants (in radiolarites); fossil shell fragments (in the fossiliferous chert); and limestone components, such as ooliths and pellets (in the siliceous limestone). All samples show distinct FTIR bands, most of which are assigned to microquartz, quartz, and fibrous microquartz. The deconvolution of the FTIR spectra in the 950-1300 $\mathrm{cm}^{-1}$ domain reveals the contribution of several other phases, such as calcite and clay minerals.

The results support the assumption that the tools made of chert, fossiliferous chert, and siliceous limestone were produced at the site from nodules that probably originated from the Upper Jurassic chert-bearing limestone that crops out nearby in the Trascău Mts. The tools made of radiolarite were most likely brought to the site as finished products from the Trascău Mts.
\end{abstract}

Published by the School of History, Classics and Archaeology, University of Edinburgh ISSN: 2055-0472. URL: http://journals.ed.ac.uk/lithicstudies/

Except where otherwise noted, this work is licensed under a CC BY 4.0 licence. 
Keywords: siliceous tools; Early Neolithic; optical microscopy; FTIR; Vinča culture; Limba-Oarda de Jos; Romania

\section{Introduction}

In the southwestern part of the Transylvanian Basin, Romania (see Figure 1), remnants of a Neolithic complex settlement were unearthed at Limba-Oarda de Jos (see Figure 2). This settlement was inhabited from the early Neolithic (Pre-Criș and Starčevo-Criş cultures) to the Middle Neolithic (Vinča culture) (Ciută \& Ciută 2015, Whittle et al. 2016). Archaeological research has resulted in a large collection of various artefacts that are presently stored at the "Ion Raica" Municipal Museum in Sebes (Alba county). This pseudo-tell site was emplaced on the Mureş River left bank near the Trascău Mts. and is ca. 4 km (in a straight line) SSE of the present-day city of Alba Iulia (see Figure 1). The location was likely strategically chosen to allow control of the routes connecting the eastern and southern areas of the Transylvanian Basin with Banat, the Pannonian Plain, and the areas beyond the Southern Carpathians (Suciu 2009).

The Vinča culture was widespread in the southeastern part of Europe and occupied a territory that predominantly corresponds to modern-day Serbia, Kosovo, as well as parts of Romania, Croatia, Bulgaria, Bosnia-Herzegovina, Montenegro, the Republic of Northern Macedonia (FTYR), and Greece (Bogosavljević 2017; Suciu 2009). The onset of this culture can be linked with the control of both the salt sources (Nandris 1990) and obsidian trade routes (Suciu 2010). The Vinča culture is characterized by particularly large tell settlements and specific ritual behaviour (Suciu 2009).

For more than twenty years, research and systematic investigations have been carried out in this archaeological site, and these efforts have resulted in the compilation of a collection of various lithic materials, including polished stone tools (over 150 axes and chisels) and more than one thousand retouched and non-retouched blade stones. The seven pieces of alabaster idols and amulets and the two zoomorphic pieces made of marble (Ciută \& Ciută 2011) previously found here are regarded as hallmarks with ritual and spiritual significance (Crnobrnja 2011).

Several petroarchaeological studies of Vincă chipped lithic tools and their raw material provenience have been carried out by Bogosavljević $(2001 ; 2016 ; 2017)$, Antonović et al. (2005), Biagi et al. (2007), Crandell (2008), and Rey-Solé et al. (2018). They documented the use of a large range of rock types, most of which were identified as quartzite and chert, i.e., "Banat flint" (Biagi et al. 2007; Comşa 1971; Crandell 2008) and "Moldavian flint" (Crandell 2012a; 2012b). Obsidian, radiolarite (Biagi et al. 2007), greenschist, dolerite, and tuff (Antonović et al. 2005) were used as well.

The aim of this investigation is to discriminate and classify 322 siliceous tools and débitage (see Figure 3) that were found at Limba-Oarda de Jos and assigned to the early Vinča culture period (Ciută et al. 2016). A combination of macroscopic and microscopic methods with infrared spectroscopy was applied in order to obtain detailed information on the composition and structure of the materials and to ultimately infer the provenance of the material.

Previous geological and archaeological research has indicated that siliceous rocks such as cherts, radiolarites, cherty limestones, and other knappable materials used in Prehistory originate from the Southern Apuseni Mts., particularly in the Metaliferi and the Trascău mountains (Crandell 2008; 2009; 2014; Herz \& Savu 1974; Lupu, 1995; Nicolae 1992). 


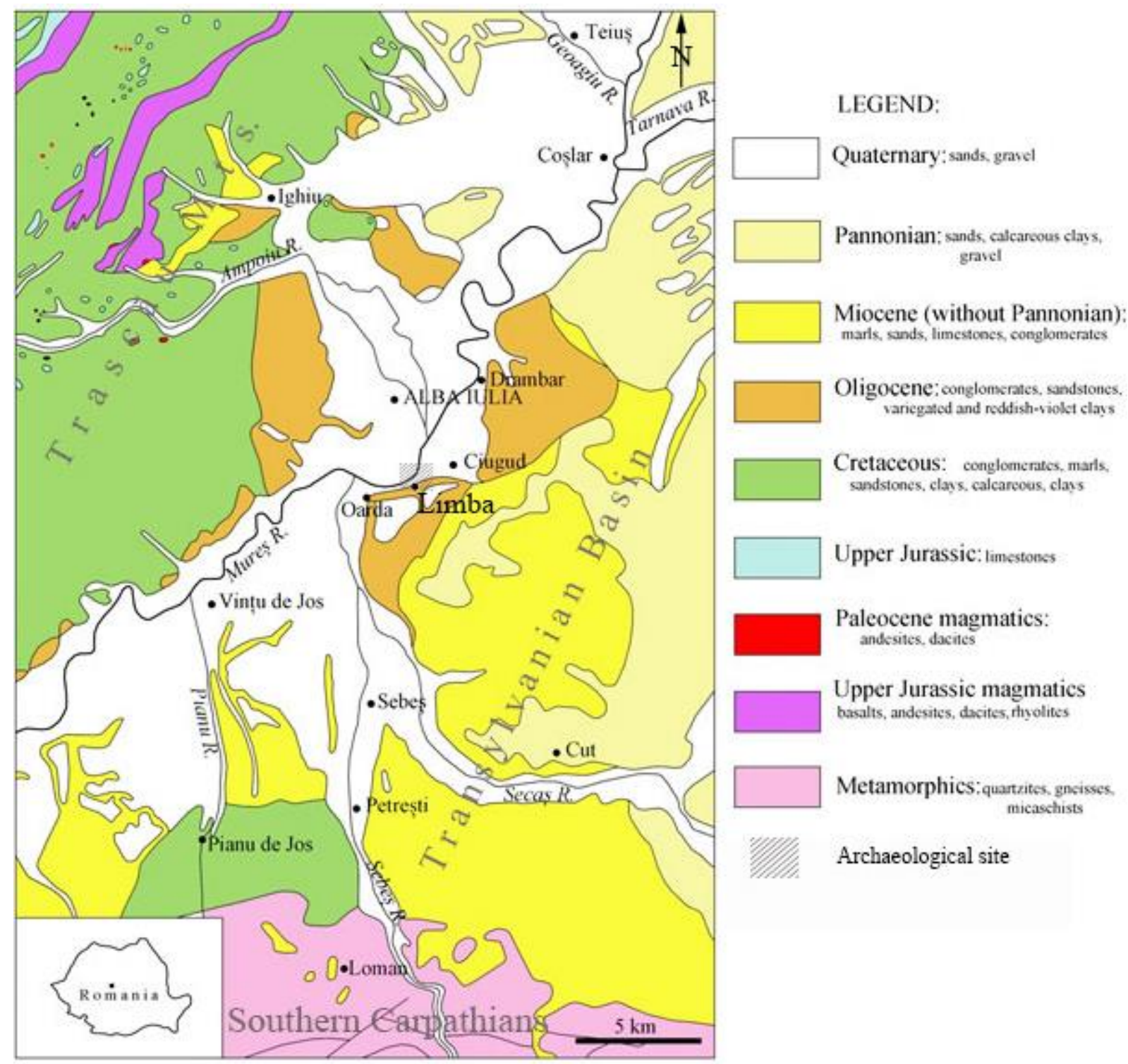

Figure 1. Location of the Vinča site at Limba-Oarda de Jos on a simplified geological map (according to Giuşcă et al. 1967) of the area. The inset in the lower left shows the position of the area within Romania.

Legend: Quaternary: sands, gravel. Pannonian: sands, calcareous clays, gravel. Miocene (without Pannonian): marls, sands, limestones, conglomerates. Oligocene: conglomerates, sandstones, variegated and reddish-violet clays. Cretaceous: conglomerates, marls, sandstones, clays, calcareous clays. Upper Jurassic: limestones. Paleocene magmatics: andesites, dacites. Upper Jurassic magmatics: basalts, andesites, dacites, rhyolites. Metamorphics: quartzites, gneisses, micaschists.

\section{Materials and methods}

A set of 322 retouched tools and débitage pieces were washed, photographed, and investigated macroscopically using an SMZ645 Nikon stereomicroscope. Twenty pieces were selected as representative of the main macroscopically defined groups (mainly débitage). From these twenty pieces, thin sliced were cut with a diamond saw and used to prepare thin sections for polarized light optical microscopy (OM). A Zeiss Axio Imager.A2m petrographic microscope (Geology Department at Babeș-Bolyai University in Cluj-Napoca) was used for microscopic and mineralogical studies. The microphotos were captured by an Axio Cam ICc5 video camera. 


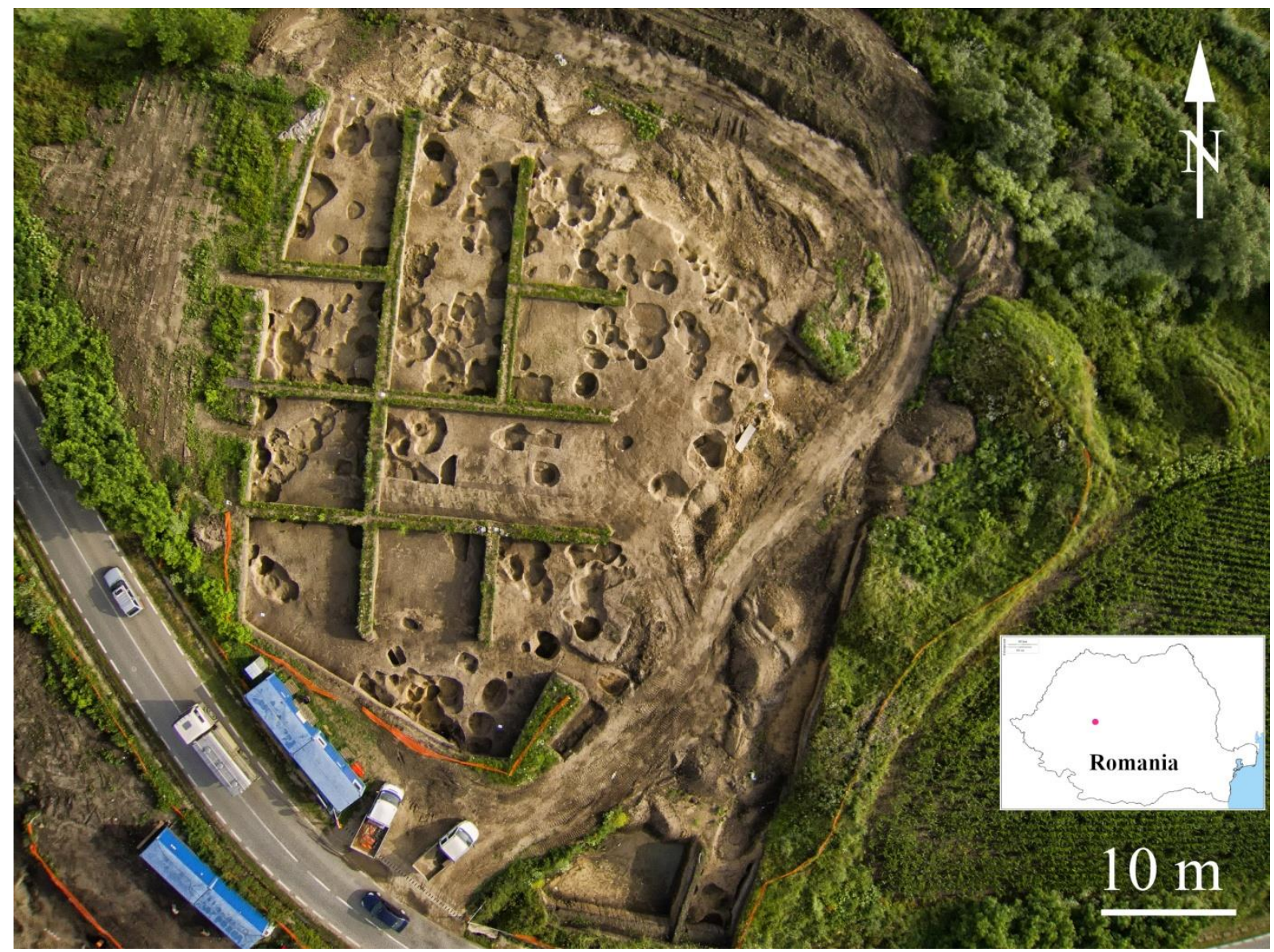

Fig. 2. Aerial view of the 2016 archaeological excavations at Limba-Oarda de Jos (Photo: M.M. Ciută; image from Ciută et al. 2016). The inset in the lower right shows the position of the area within Romania (modified from D-maps.com (2019)).

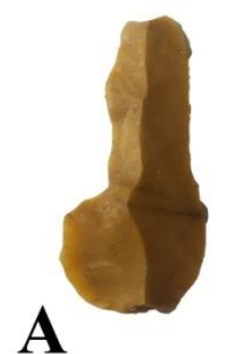

A
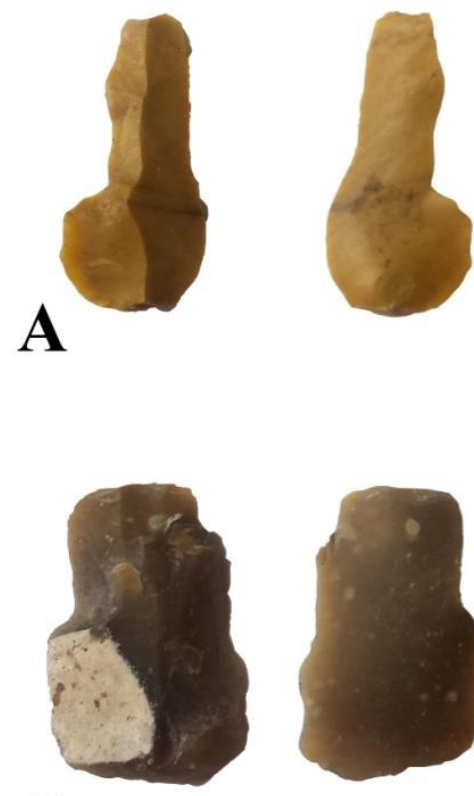

C

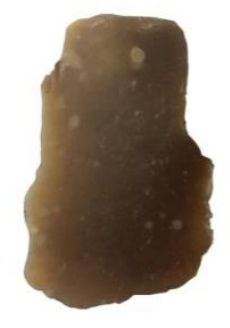

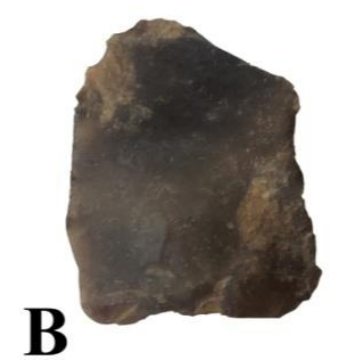
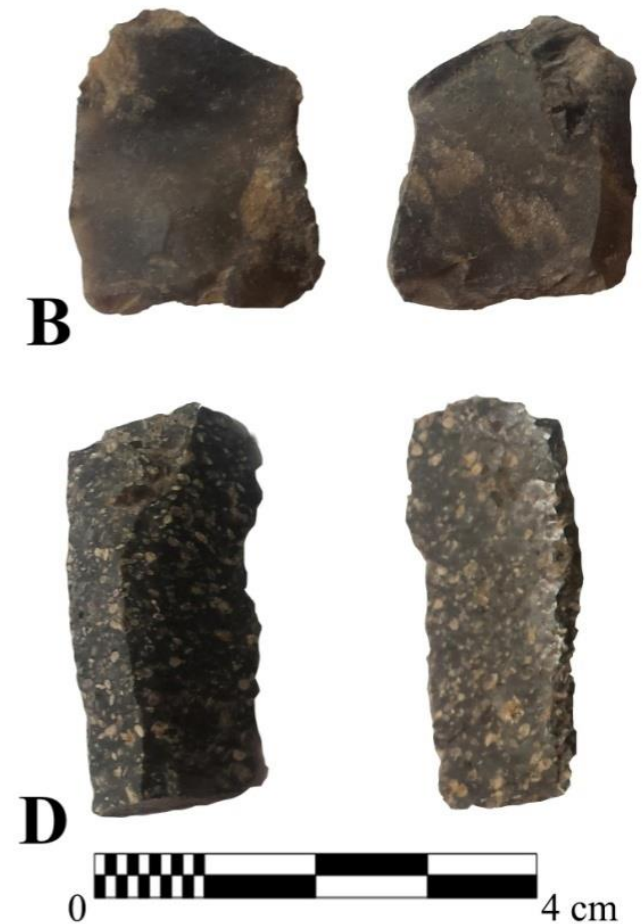

Figure 3. Detailed macroscopic images (dorsal and ventral) of some of the studied lithics from Limba-Oarda de Jos. A: flake, sample 4472. B: fragment (débitage), sample 4576(15). C: flake, sample 4446. D: blade, sample 4469 (from Rey-Solé et al. 2018). 
Information on the composition and microstructure of the material was obtained by analysing ten of the twenty pieces by Fourier-transform infrared spectroscopy (FTIR) using a JASCO 6200 spectrometer (Nanostructured Materials and Bio-Nano-Interface Center in the Interdisciplinary Research Institute on Bio-Nano-Sciences at Babeş-Bolyai University in Cluj-Napoca). From $\sim 1.2 \mathrm{mg}$ of hand-milled sample mixed with $150 \mathrm{mg} \mathrm{KBr}$, pellets with a $13 \mathrm{~mm}$ diameter were prepared under 5 tonnes of pressure. The spectrometer was operated with 256 scans in the spectral range of $4000-400 \mathrm{~cm}^{-1}$ and a resolution of $4 \mathrm{~cm}^{-1}$. The spectra were analysed using Spectra Analysis software. For detailed compositional information, deconvoluted spectra in the $1300-950 \mathrm{~cm}^{-1}$ domain were obtained.

\section{Results and discussion}

\subsection{Macroscopic observation}

The macroscopic parameters analysed were based on those described by Luedtke (1992), Crandell (2005; 2006), Tarriño (2006), and Rey-Solé (2016). They include the shape (typology) and size, as well as the fabric, lustre, translucency, grain size, colour (from Munsell 1975), and pattern. The great variability in the appearance of the samples provided the criteria for distinguishing and grouping them. Four different groups were discriminated according to their abundance in the site, as described in the following paragraphs (see Table 1 and Figure 3).

Table 1. Typology, size, colour, and petrographic types of the representative samples.

\begin{tabular}{lllll}
\hline Sample no. & Typology & Size (mm) & Munsell colour & Petrographic type \\
\hline 4379 & Flake & $39 \times 2 \times 18$ & Dark grey (2.5YR N4) & Radiolarite \\
4472 & Fragmented blade & $25 \times 13 \times 4$ & Olive yellow $(2.5 Y 6 / 8)$ & Radiolarite \\
$4350(2)$ & Fragmented flake & $2 \times 2 \times 4$ & Dark brown (7.5 YR 3/2) & Chert \\
4419 & Blade & $4 \times 16 \times 6$ & Dark yellowish brown (10YR 4/4) & Chert \\
$4576(15)$ & Fragment (débitage) & $26 \times 22 \times 8$ & Very dark greyish brown (2.5Y 3/2) & Chert \\
$4576(19)$ & Fragment (débitage) & $35 \times 28 \times 14$ & Very dark greyish brown (2.5Y 3/2) & Chert \\
$4622(2)$ & Blade & $42 \times 14 \times 5$ & Brownish yellow (10YR 6/6) & Chert \\
$4497(7)$ & Blade & $36 \times 14 \times 4$ & Dark yellowish brown (10YR 3/6) & Fossiliferous chert \\
$4542(2)$ & Fragment (débitage) & $21 \times 22 \times 4$ & Dark yellowish brown (10YR 3/6) & Fossiliferous chert \\
$4576(12)$ & Fragment (débitage) & $38 \times 32 \times 16$ & Very dark greyish brown (2.5Y 3/2) & Fossiliferous chert \\
$4576(13)$ & Fragment (débitage) & $27 \times 21 \times 3$ & Brown/dark brown (10YR 4/3) & Fossiliferous chert \\
4446 & Fragmented blade & $27 \times 19 \times 3$ & Dark yellowish brown (10YR 3/6) & Fossiliferous chert \\
$4576(16)$ & Flake & $34 \times 36 \times 3$ & Black (5Y 2.5/2) & Fossiliferous chert \\
4574 & Fragment of blade & $31 \times 18 \times 3$ & Dark yellowish brown (10YR 3/6) & Siliceous limestone \\
4440 & Truncated blade & $31 \times 15 \times 3$ & Light olive brown (2.5Y 5/4) & Siliceous limestone \\
$4576(18)$ & Fragment (débitage) & $37 \times 2 \times 5$ & Dark yellowish brown (10YR 3/6) & Siliceous limestone \\
4469 & Truncated blade & $3 \times 12 \times 7$ & Very dark brown (10YR 2/2) & Siliceous limestone \\
4599 & Fragment of blade & $27 \times 15 \times 7$ & Light olive brown (2.5 Y 5/4) & Siliceous limestone \\
\hline
\end{tabular}

The first group consists of 41 samples $(12.73 \%$ of the total) that are mostly homogeneous in appearance and have a waxy shine. The pieces are opaque to sub-translucent, very fine grained, and olive yellow in colour (2.5Y 6/8)(Munsell 1975). Ten pieces from this group display a mottled and stripped aspect. Macroscopically, the pieces are defined as radiolarites. Typologically, the group is composed of 24 blades and fragmented blades ( 8 of them are assigned to the stripped subgroups, and 4 pieces are retouched on one side), 4 flakes and fragmented flakes (débitage), 10 fragments (débitage), and 3 cores. The blades range from 30 to $45 \mathrm{~mm}$ in length and from 5 to $20 \mathrm{~mm}$ in width, and the flakes range from 18 to $15 \mathrm{~mm}$ in length and from 12 to $15 \mathrm{~mm}$ in width (see Table 1). 
The second group is composed of 86 samples $(26.71 \%$ of the total) with a heterogeneous, dull, opaque, and fine- to medium-grained appearance and a dark greyish brown colour $(2.5 \mathrm{Y}$ 3/2)(Munsell 1975). Typologically, this group consists of 24 blades and fragmented blades, 18 flakes and fragmented flakes (débitage), 43 fragments (débitage) and 1 core. The length of the blades (most of which are truncated blades) ranges from 15 to $45 \mathrm{~mm}$, and the width ranges from 8 to $25 \mathrm{~mm}$. The flakes range in length from 15 to $45 \mathrm{~mm}$ and in width from 15 to $44 \mathrm{~mm}$. Some pieces show remnants of cortex. Macroscopically, the pieces are defined as being made of a type of rough chert.

The third group consists of 90 samples (27.95\% of the total) with a homogeneous, shiny, and translucent to sub-translucent appearance. They are very fine to fine grained, and the colour (Munsell 1975) ranges from dark yellowish brown (10YR 3/6) to black (10YR 2/1). Typologically, this group is composed of 40 blades and fragmented blades, 7 of which have only one side retouched. Thirty flakes and fragmented flakes, 19 fragments (débitage), and 1 core also belong to this group. The blades range in length from 10 to $38 \mathrm{~mm}$ and in width from 10 to $18 \mathrm{~mm}$. The sizes of the flakes are more variable, ranging from 18 to $45 \mathrm{~mm}$ in length and from 10 to $30 \mathrm{~mm}$ in width. Fifteen samples in this group have cortex remains. Macroscopically, the pieces are defined as being made of a type of fine chert.

The fourth group consists of 105 samples $(32.60 \%$ of the total) with a heterogeneous appearance and a greasy shine. They are opaque and medium to coarse grained and the colour (Munsell 1975) ranges from very dark brown (10YR 2/2) to light brownish grey (10YR 6/2). Macroscopically, the pieces are defined as being made of siliceous limestone. Typologically, this group is composed of 45 blades (of which 24 are truncated) and fragments of blades, 33 flakes and fragmented flakes, 25 fragments (débitage) and 2 cores. The blades range from 23 to $53 \mathrm{~mm}$ in length and from 9 to $17 \mathrm{~mm}$ in width, whereas the flakes range from 11 to $52 \mathrm{~mm}$ in length and from 9 to $51 \mathrm{~mm}$ in width. Seven pieces (6 flakes and 1 core) from this group show cortex remains.

\subsection{Polarized light optical microscopy}

On the basis of the mineralogical features (composition and fabric, i.e., structure and texture) observed in the thin sections, four main petrographic types are discriminated: radiolarite, chert, fossiliferous chert, and siliceous limestone (Figure 4 A1-D2). The analysed microscopic parameters, including the description and classification, are based on those described by Dunham (1962), Knauth (1994), Tarriño (1998), Graetsch (1994), Knauth (1994), Bustillo et al. (2009), Přichystal (2010) and Ionescu \& Hoeck (2018). Despite having variable macroscopic features, the chert samples are highly homogeneous microscopically.

\section{Radiolarite (samples 4379 and 4472)}

The samples studied consist of a microquartzitic mass (less than 100 micrometres in size) and an abundance of whole spherical or fragments of radiolarian tests. The latter range from 50 to 200 micrometers in size (Figure 4 A1 and A2) and most of them are replaced by fibrous microquartz ('chalcedony').

\section{Chert (samples 4350(2), 4576(15), 4576(19), 4622(2), and 4419))}

The analysed samples reveal a granular microquartzitic matrix (grains less than 20 micrometers in size) with rare remnants of foraminifera tests and other undetermined bioclasts. Some fossil tests are replaced by fibrous microquartz that grades inward into megaquartz (see Figure 4 B1). The rock also contains clusters of megaquartz crystals (see Figure 4 B2). 

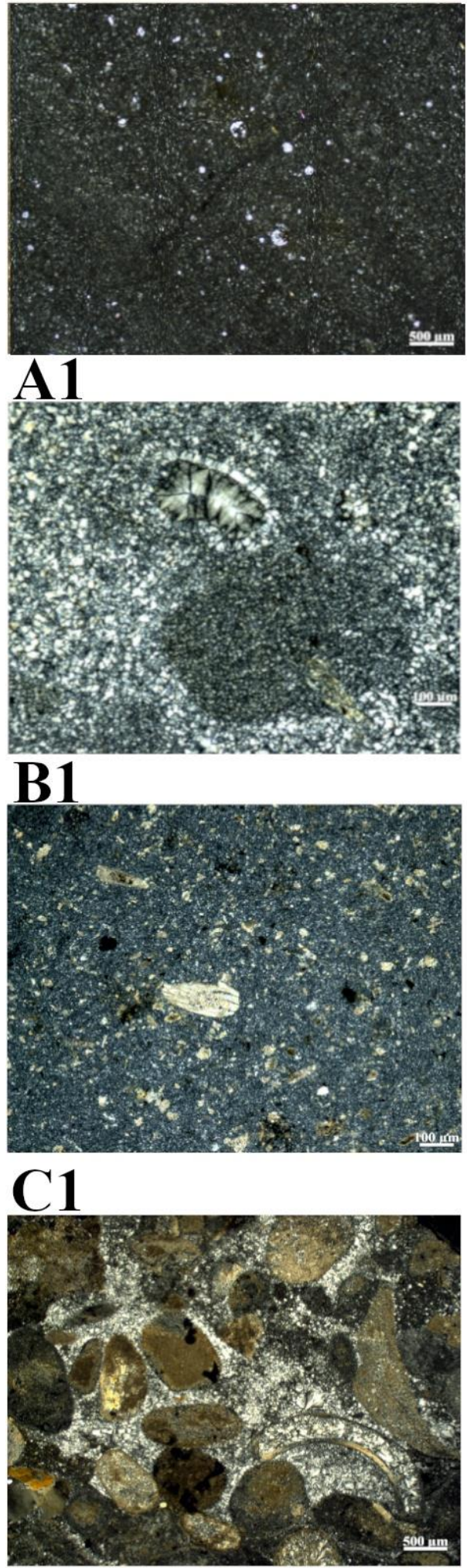

D1
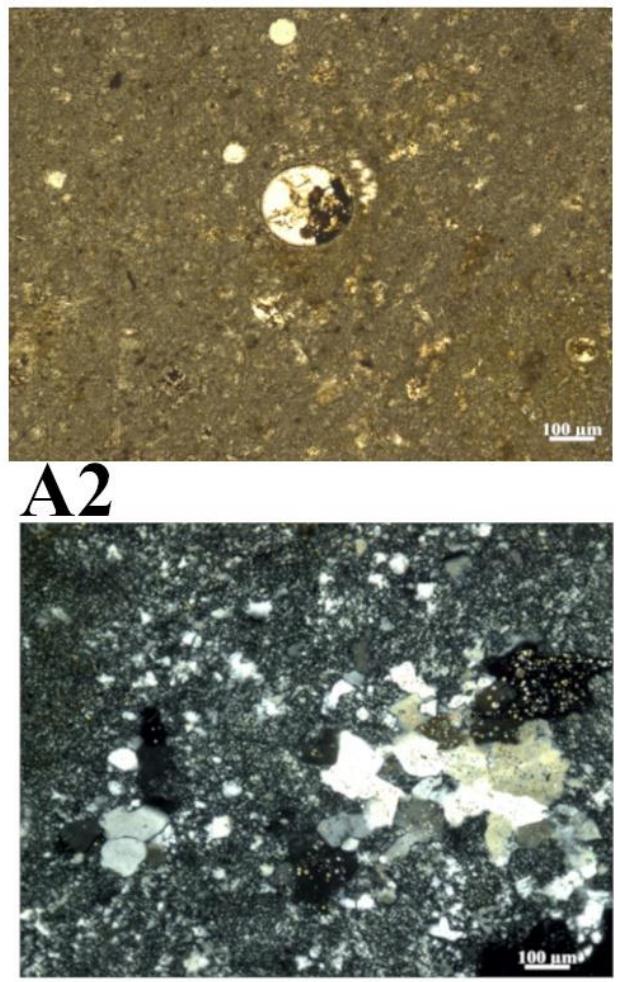

B2

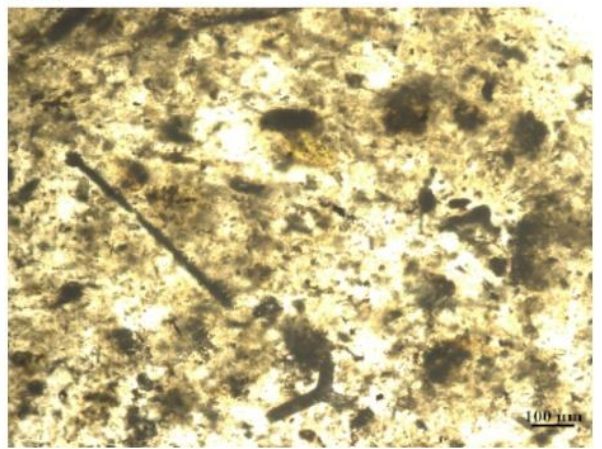

C2

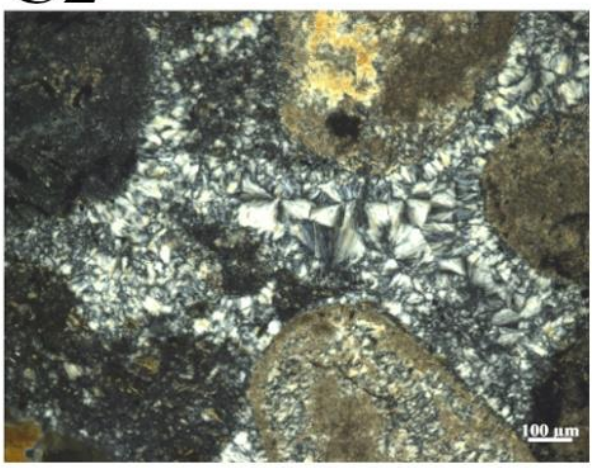

D2

Figure 4. Polarized light optical microphotos: A - Radiolarite: general view of sample (A1) and radiolarian test in detail (A2); B - Chert: microfossil replaced by chalcedony that grades inward into megaquartz (B1) and a cavity filled by a mosaic of megaquartz (B2); C - Fossiliferous chert: a shell fragment in a fine-grained mass of microquartz $(\mathrm{C} 1)$ and monaxon and triaxon sponge spicules in chert (C2); D - Siliceous limestone (Grainstone) with ooliths in siliceous cement made of microquartz (D1) and fibrous microquartz filling spaces among clasts (D2). All images with crossed polarizers, except A1 and C2 (one polarizer). Images A1, B1, C1, and D1 are from Rey-Solé et al. (2018). 


\section{Fossiliferous chert (4446, 4497(7), 4542(2), 4576(12), 4576(13), and 4576(16))}

The parent rock of these samples was a limestone (wackestone) containing a great diversity of marine microfossils. The carbonate rock is replaced by a microquartzitic matrix. The fossil tests are made of carbonate or are replaced by a mass of fibrous quartz. There are remnants of a wide range of fossil types: bivalves (see Figure $4 \mathrm{C} 1$ ), distinct sections of calcareous triaxon and monaxon spicules (see Figure $4 \mathrm{C} 2$ ), vegetal remains, foraminifera, and fragments of undetermined fossils. In some parts, the rock is heterogeneous owing to a concentration of reddish brown iron oxides and organic matter.

\section{Siliceous limestone (samples 4440(1), 4469, 4574, 4576(18), and 4599)}

These samples show an oolithic and pelletal texture, which was most likely inherited from a parental grainstone. These particles range from 100 micrometers to almost $1 \mathrm{~mm}$ in diameter (see Figure 4 D1). The limestone is intensely silicified and a fine microquartzitic material cements the ooliths and the pellets. There are also abundant fragments of marine organisms, such as foraminifera, thecal plates (grill texture) of echinoids, fragments of bivalves and other fragments of unknown origin. Most of the clasts consist of carbonate. Nevertheless, several bioclasts are replaced by either fibrous microquartz ('chalcedony') or by megaquartz (see Figure 4 D2). In addition, opaque minerals are detected.

\subsection{Fourier-transform infrared spectroscopy}

Fourier-transform infrared spectroscopy (FTIR) is employed for a wide range of materials used in lithic technology. It helps in the identification of microcrystalline and amorphous silica (Banerjee 1993; Handke and Mozgawa 1993), as well as various opals (Adamo et al. 2010). Therefore, this analytical technique can be regarded as essential to the study of siliceous artefact composition and the acquisition of information about the crystallinity of silica minerals (Hlavay et al. 1978).

The spectra obtained for the ten samples (one radiolarite, three cherts, three fossiliferous cherts and three siliceous limestones) are shown in Figure 5. All samples produced Si-O stretching vibrations at 462, a 781-797 doublet, and at $\sim 1089 \mathrm{~cm}^{-1}$, which is characteristic of quartz (Kieffer 1979; Moenke 1974), and an almost indistinct and broad band centred at $\sim 3500 \mathrm{~cm}^{-1}$ that is due to the water content (up to 2 mass \%) found in chert (Knauth 1994). This signal can also be linked to H-O-H vibrations of adsorbed water (Madejová 2003) or to $\mathrm{OH}$ groups in some clay minerals, which may be present as impurities. The samples made of fossiliferous chert and siliceous limestones have wide bands at 1425 and $878 \mathrm{~cm}^{-1}$ that are generated by $\mathrm{CO}_{3}$ vibrations (Fabbri et al. 2014; Shoval 2003) and normally assigned to calcite content (Kieffer 1979). The 695 and $464 \mathrm{~cm}^{-1}$ signals are due to Si-O bending vibrations in crystalline materials, i.e., quartz.

To identify the compounds that contribute to the main FTIR signal centred at $\sim 1089 \mathrm{~cm}^{-1}$ (see Figure 5), the spectra were deconvoluted in the 950-1300 $\mathrm{cm}^{-1}$ domain (see Figures 6 A$\mathrm{D}$ and 7 A-F; Table 2). The fitted spectrum (not shown here) overlaps the experimental one. There are three main components in each spectrum, except for one siliceous limestone sample (4576(18)). Radiolarite, chert, fossiliferous chert, and siliceous limestone show similar compositions, which are basically quartzitic (microquartz), with their main signals appearing at $1088-1090 \mathrm{~cm}^{-1}$ (Handke \& Mozgawa 1993). Each sample also shows similar amounts of a secondary compound, as evidenced by the $1168-1175 \mathrm{~cm}^{-1}$ signal. This can be assigned to quartz (De Benedetto et al. 2002; Kieffer 1979; Handke \& Mozgawa 1993) and fibrous microquartz (Banerjee 1993). The third signal at $1018-1019 \mathrm{~cm}^{-1}$ is weak. It is shifted to a 
higher wavenumber $\left(1035 \mathrm{~cm}^{-1}\right)$ in one chert sample (see Figure $\left.6 \mathrm{D}\right)$. This FTIR band can be produced by Si-O-Al vibrations in clay minerals (De Benedetto et al. 2002).

The ratio between the intensity (expressed here as the measured area of the signal) of the component signals in the deconvoluted spectra (see Table 2) show that the main signal (centred at $\sim 1088-1090 \mathrm{~cm}^{-1}$ ) is generally 2-3 times larger than the second one (centred at $\sim 1168-1176 \mathrm{~cm}^{-1}$ ). The contribution of the third signal is insignificant.

The narrow bands assigned to quartz prove the prevalence of the (micro)crystalline form of quartz in all samples studied. It is both microquartz and fibrous microquartz (sensu Graetch 1994). There is no association of specific bands at $1638+1102+789$ (single band) $+475 \mathrm{~cm}^{-}$ ${ }^{1}$ (Caucia et al. 2012); hence, no opal CT occurs in our samples.

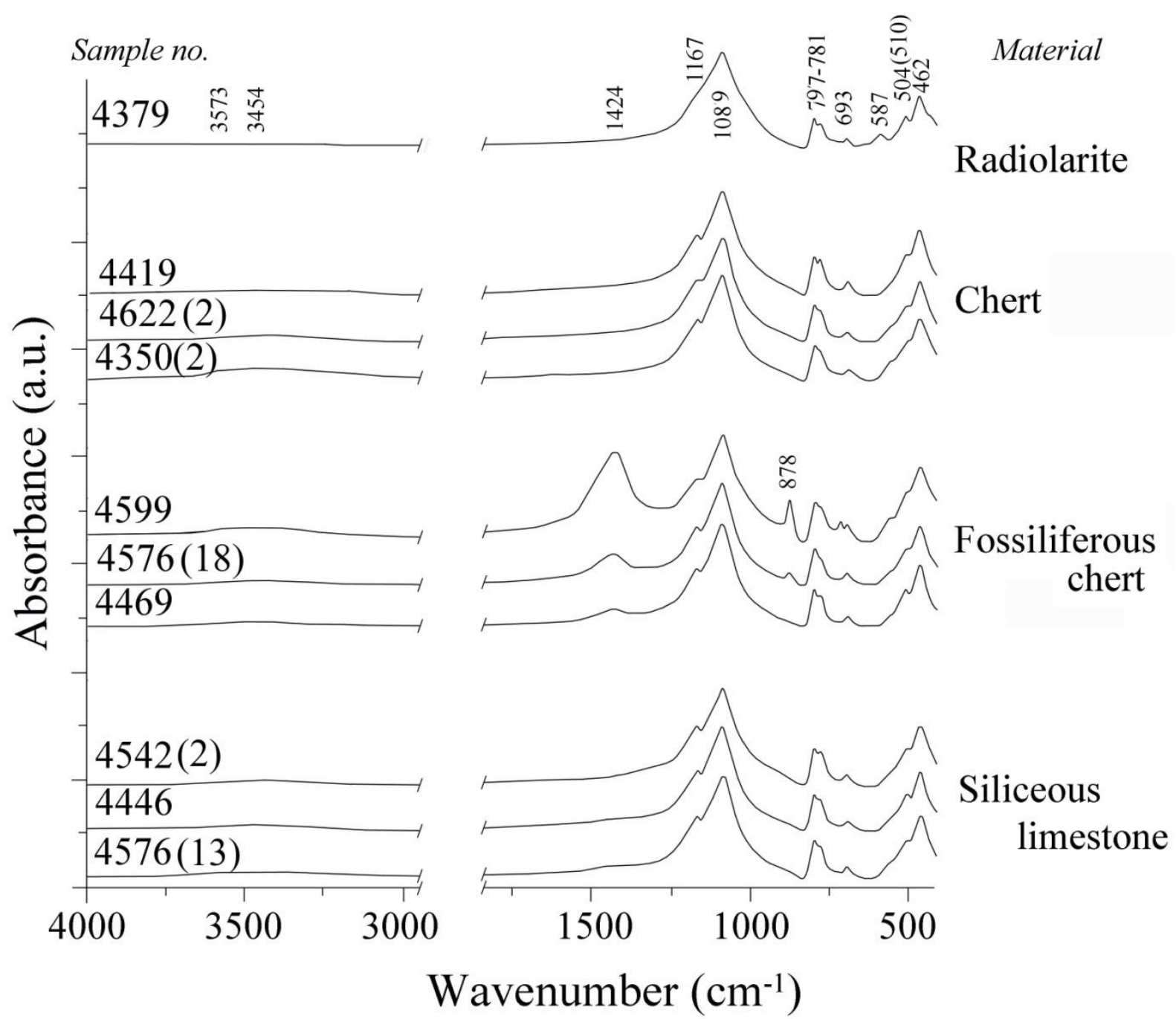

Figure 5. The pattern of the FTIR spectra for radiolarite, chert, fossiliferous chert, and siliceous limestone pieces in the $4000-500 \mathrm{~cm}^{-1}$ region. (Image from Rey-Solé et al. 2018). 
A

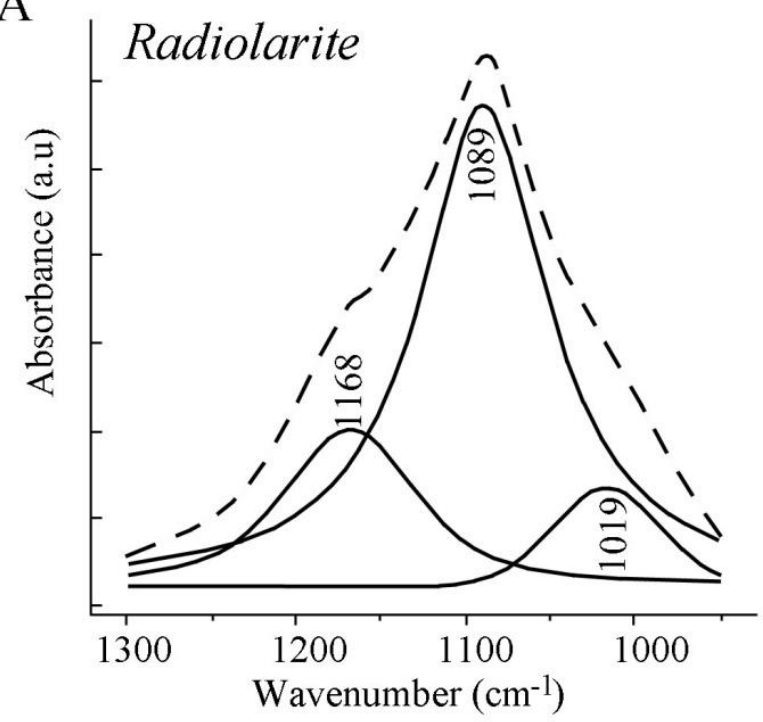

$\mathrm{C}$

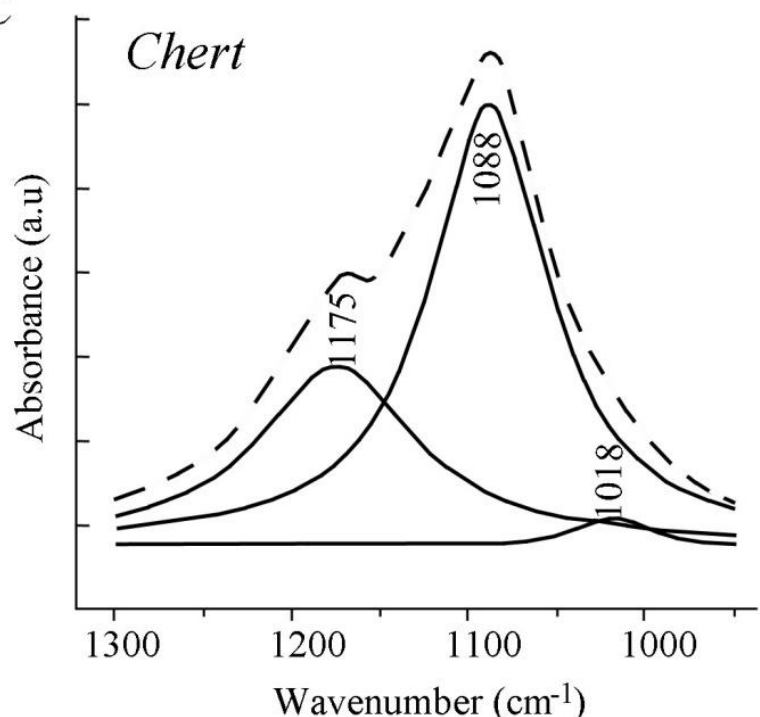

B

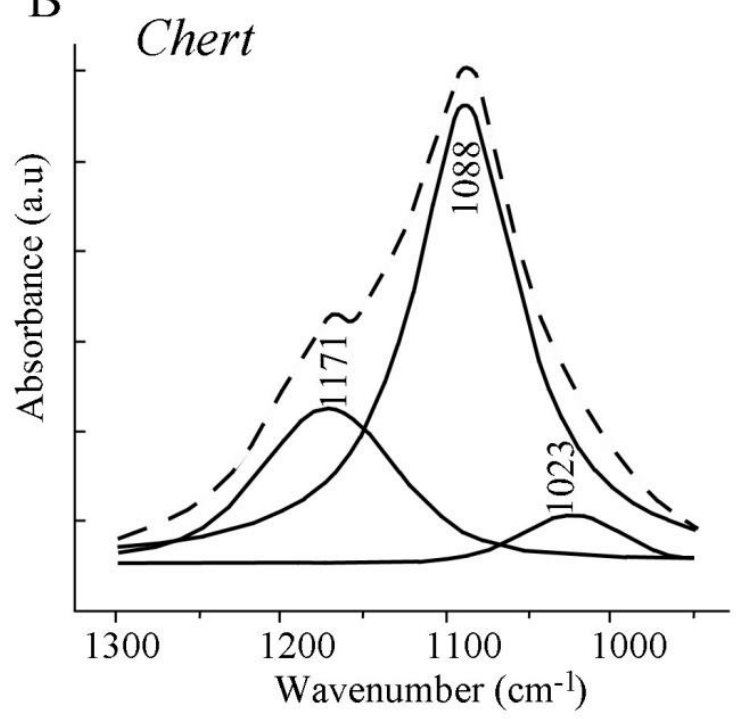

$\mathrm{D}$

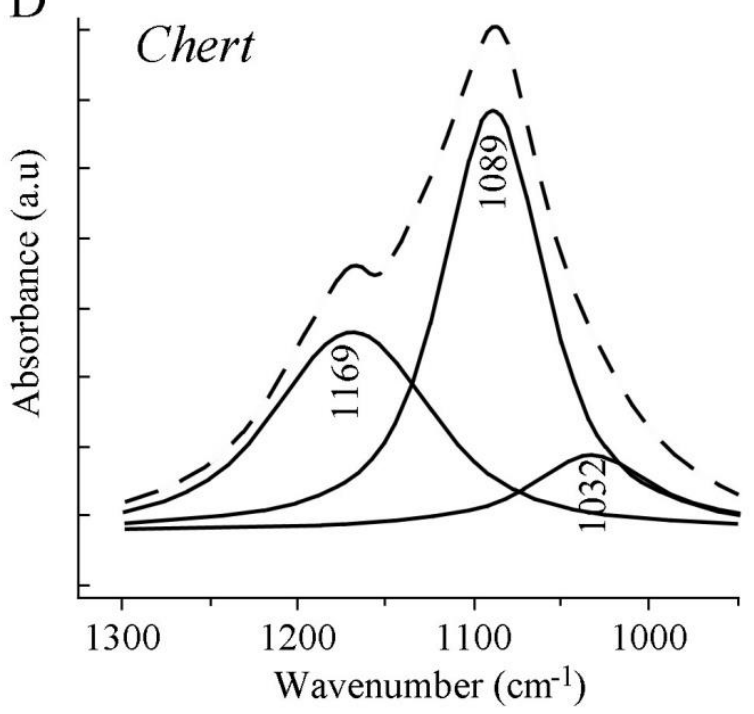

Figure 6. Experimental and deconvoluted spectra in the 1300-950 $\mathrm{cm}^{-1}$ range for (A) Radiolarite; sample 4379; (B, C, and D) Chert; samples 4419, 4622(2), and 4350(2). The experimental spectrum is drawn with a dashed line. 

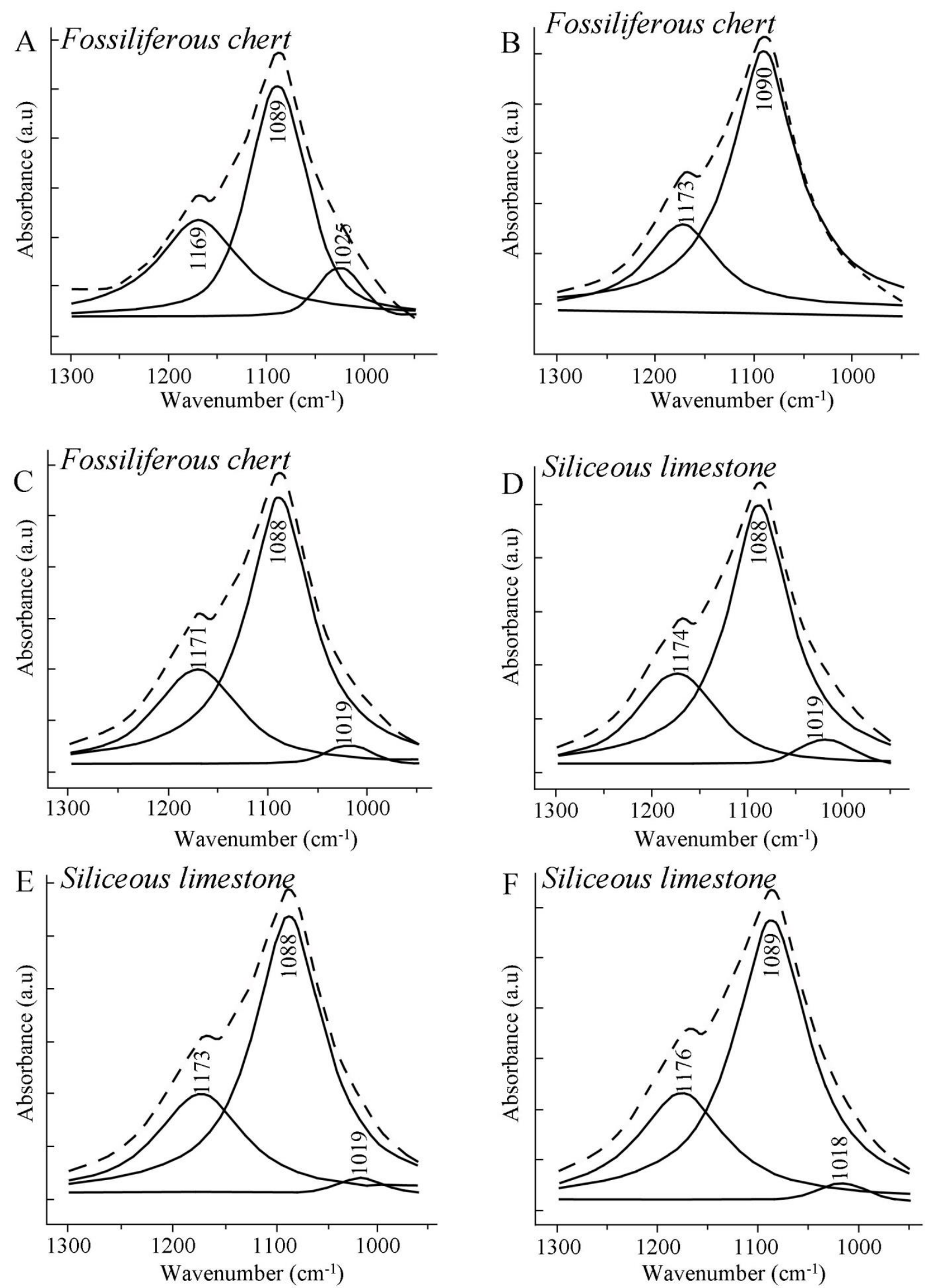

Figure 7. Experimental, fitted, and deconvoluted spectra in the $1300-950 \mathrm{~cm}^{-1}$ range for (A, B, and C) Fossiliferous chert: samples 4599, 4576(18), and 4469; (D, E and F) Siliceous limestone: samples 4542(2), 4446, and 4576(13). The experimental spectrum is drawn with a dashed line. 
Table 2. The wavenumbers for the component signals of deconvoluted spectra and the ratio between the intensity (I) of each signal.

\begin{tabular}{lllllll}
\hline & & \multicolumn{2}{c}{ Component $\left.\mathbf{( c m}^{-\mathbf{1}}\right)$} & $\mathbf{I}_{(\mathbf{1})}: \mathbf{I}_{(\mathbf{2})}: \mathbf{I}_{(\mathbf{3})}$ & $\mathbf{I}_{(\mathbf{2})} / \mathbf{I}_{(\mathbf{1})}$ \\
Petrographic type & Sample no. & $\mathbf{( 1 )}$ & $\mathbf{( 2 )}$ & $\mathbf{( 3 )}$ & areas ratio (a.u.) & \\
\hline Radiolarite & 4379 & 1168 & 1089 & 1019 & $29: 103: 11$ & 3.55 \\
\hline Chert & 4419 & 1171 & 1088 & 1023 & $32: 95: 6$ & 2.97 \\
& 4622 & 1174 & 1088 & 1018 & $53: 100: 2.2$ & 1.89 \\
& 4350 & 1169 & 1089 & 1032 & $50: 73: 17$ & 1.46 \\
\hline Fossiliferous chert & 4599 & 1169 & 1089 & 1025 & $43: 60: 7.7$ & 1.40 \\
& $4576(18)$ & 1173 & 1090 & - & $32: 100$ & 3.13 \\
& 4469 & 1171 & 1088 & 1019 & $39: 97: 3$ & 2.49 \\
\hline Siliceous limestone & 4542 & 1174 & 1088 & 1019 & $35: 92: 5$ & 2.63 \\
& 4446 & 1173 & 1088 & 1019 & $42: 101: 2.5$ & 2.40 \\
& $4576(13)$ & 1176 & 1089 & 1018 & $48: 108: 2.7$ & 2.25 \\
\hline
\end{tabular}

\section{Discussion}

Microscopic features facilitate the clear separation of the samples into petrographic groups. Radiolarite, chert, fossiliferous chert and siliceous limestone show a primarily quartzitic composition that is represented by microquartz, quartz and fibrous microquartz. The FTIR spectra of the analysed samples show small differences that are largely due to the contribution of other compounds, such as carbonates and occasionally clay minerals. However, the signals are distinct for each petrographic group because of their compositional differences. These FTIR signals may help separate samples containing only small amounts of these compounds, for example, carbonate in radiolarite.

However, a clear link is found by comparing the mineralogical-petrographic features of the lithic tools found at Limba-Oarda de Jos with those of suitable rocks from the surroundings. Geologically, the area is located at the contact point between the Trascău Mts. (part of the Southern Apuseni Mts.) to the west and northwest, the Transylvanian Basin to the east, and the Southern Carpathians to the south (as seen in Figure 1). In the Trascău Mts., there are formations of interest to the lithic industry, such as the Upper Jurassic chert-bearing limestones, Upper Jurassic radiolarites, as well as Cretaceous conglomerates, sandstones, clays, and limestones (Giușcă et al. 1967; Ionescu \& Hoeck 2010; Săndulescu 1984; Săsăran 2006). The mineralogical and petrographic features of the lithic tools fit well with those described for the above-mentioned geological formations. Hence, the Upper Jurassic chertbearing limestones and the Upper Jurassic radiolarites can be envisaged as possible sources of the cherts, siliceous limestones, and radiolarites used to produce the Middle Neolithic lithic tools found at Limba-Oarda de Jos.

Biró and Dobosi (1991), Biagi et al. (2007) and Starnini et al. (2015) concluded that two kinds of radiolites, the Mecsek and the Úrkut Transdanubian radiolarites, which were frequently used to produce stone tools, originate from the Mecsek Mts. and the Bakoni Mts. (Hungary), respectively. In addition, Biagi and Voytek (2006) assumed an exogenous provenance of the Úrkút Transdanubian radiolarite pieces found at the Peștera Ungurească (Caprelor Cave) in the Turda Gorges, which is in the northern end of the Trascău Mts., showing the long-distance travel undertaken with this exotic raw material. In our case, the small number of radiolarite tools, cores, and débitage found in situ cannot be underestimated; therefore, a comparative study with Transdanubian radiolarite could shed light on the provenance and, possibly, trade routes. 


\section{Conclusions}

At the Neolithic site at Limba-Oarda de Jos (Romania), four rock types were used to produce various tools. Among them, chert, fossiliferous chert, and siliceous limestone were the most frequently used, whereas radiolarite was used to a lesser extent. The typological analysis in relation to petrography reveals a preference for the manufacture of blades from all rock types, with some differences; e.g., the blades made of siliceous limestone are larger than the blades made of other rock types.

The large number of cores and débitage made of chert, fossiliferous chert, and siliceous limestone suggests that the lithic raw material was transported as nodules and that the tools were chipped in situ at the settlement. These nodules most likely originate from the Trascău Mts., where Upper Jurassic limestones (Ionescu \& Hoeck 2010) crop out (see Figure 1). By contrast, the small number of radiolarite cores and débitage indicates these materials were initially processed at the source and subsequently transported to the settlement as finished products. Although there are other important radiolarite outcrops, such as the Mecsek Mts. and Bakoni Mts. (Hungary) (Biagi et al. 2007; Biró \& Dobosi 1991; Biagi \& Voytek 2006; Starnini et al. 2015), the Upper Jurassic radiolarites that co-occur with the Upper Jurassic limestones are close to the Limba-Oarda de Jos site. This factor may have been a reason for choosing them instead of other distant radiolarite outcrops in the Southern Apuseni Mts.

The present petroarchaeological study of siliceous lithic tools from Limba-Oarda de Jos is part of a larger outgoing project focused on the provenance of lithic raw materials at different Paleolithic and Neolithic archaeological sites of Transylvania (Romania). Lithic tools and their raw materials are regarded as spatial-temporal markers. Their lithological analysis and geological contextualization allow researchers to define which territories were controlled at a certain time (Mangado 2006).

\section{Acknowledgements}

This contribution is possible thanks to the UEFISCDI project $P N-I I I-P 1-1.1-P D-2016$ 0859 granted to M.R-S. by the Romanian Ministry of Research and Innovation. C.I. acknowledges the support of the Russian Government Program of Competitive Growth of Kazan Federal University.

\section{References}

Adamo, I., Ghisoli, C. \& Caucia, F. 2010, A contribution to the study of FTIR spectra of opals. Neues Jahrbuch für Mineralogie - Abhandlungen, 187(1): 63-68. doi:10.1127/0077-7757/2010/0161

Anonymous 2019, d-maps.com. d-maps. Retrieved 1 January 2019. URL: https://d-maps.com/

Antonović, D., Resimić-Šarić, K. \& Cvetković, V. 2005, Stone raw materials in the Vinča culture: Petrographic analysis of assemblage from Vinča and Belovode. Starinar, 55: 53-66. doi:10.2298/sta0555053a

Banerjee, A. 1993, Notizen: Investigation of the crystallinity of the modifications of silica by their IR-reflectance spectra. Zeitschrift für Naturforschung A, 48(5-6): 741-742. doi:10.1515/zna-1993-5-630

Biagi, P., Gratuze, B. \& Boucetta, S. 2007, New data on the archaeological obsidians from the banat and Transylvania (Romania). In: A short walk through the Balkans: The first farmers of the Carpathian Basin and adjacent regions (Spataro, M. \& Biagi, P., Eds.), Quaderno Vol. 12. Società Preistoria Protostoria Friuli-V.G., Trieste: p. 129-148. 
Biagi, P. \& Voytek, B.A. 2006, Excavation at Pestera Ungureascǎ (Caprelor) (Cheile Turzii, Petrești de Jos, Transylvania) 2003-2004: A preliminary report on the chipped stone assemblages from the Chalcolithic Toarte Pastilate (Bodrogkevesztúr) layers. Analele Banatului, S.N., Arheologie-Istorie, 14(1): 177-202.

Biró, K. \& Dobosi, V.,1991, LITOTHECA - Comparative Raw Material Collection of the Hungarian National Museum, Hungarian National Museum, Budapest, 268 p.

Bogosavljević Petrović, V. 2001, New results of the study of chipped stone industry of the Vinča culture. Viminacium, 12: 35-50.

Bogosavljević Petrović, V. 2016, An archaeological experiment and new knowledge about the chipped stone industry from the Vinča culture. Journal of Lithic Studies, 3(2): 19 p. doi:10.2218/jls.v3i2.1437

Bogosavljević Petrović, V., Jovanović, D., Stojanović, M.M. \& Andrić, V. 2017, The origin, production and use of quartz crystals in the Neolithic of Serbia: Vinča-Belo Brdo. Quaternary International, 429: 24-34. doi:10.1016/j.quaint.2015.10.063

Bustillo, M.A., Castañeda, N., Capote, M., Consuegra, S., Criado, C., Díaz-del-río, P., Orozco, T., Pérez-jiménez, J.L. \& Terradas, X. 2009, Is the macroscopic classification of flint useful? A petroarchaeological analysis and characterization of flint raw materials from the Iberian Neolithic mine of Casa Montero. Archaeometry, 51(2): 175196. doi:10.1111/j.1475-4754.2008.00403.x

Caucia, F., Marinoni, L., Bordoni, V., Ghisoli, C. \& Adamo, I. 2012, Physical and chemical properties of some Italian opals. Periodico di Mineralogia, 81(1): 93-106. doi:10.2451/2012pm0006

Ciută, M.M. \& Ciută, E.B. 2011, Două piese de plastică minoră zoomorfă, vinčiene, descoperite la Limba-Bordane şi Alba Iulia-Lumea Nouă (jud. Alba). Terra Sebus, Acta Musei Sabesiensis, 5: 11-30. (in Romanian) ("Two Vincă zoomorphic small pieces discovered at Limba-Bordane şi Alba Iulia-Lumea Nouă (jud. Alba)")

Ciută, M.M. \& Ciută, E.B. 2015, New considerations about Neolithic development habitation in the archaeological site Limba-Oarda de Jos (Alba county). Acta Terrae Septemcastrensis, 14: 49-83.

Ciută, M.M., Totoianu, R., Şuteu, C., Codrea, I.C., Ciută, E.B., Bobînă, B. \& Bărbat, A. 2016, Consideraţii preliminare privind cercetările preventive din situl nr. 6, aparţinând Lotului 1 al Autostrăzii Sebeş-Turda (jud. Alba). Terra Sebus, Acta Musei Sabesiensis, 8: 9-22. (in Romanian) ("Preliminary considerations on preventive research at Site No. 6, belonging to Lot 1 of the Sebeş-Turda Motorway")

Crandell, O.N. 2005, Macroscopic analysis and characterisation of chert for provenance purposes. Sargetia, Acta Musei Devensis, 33: 137-153.

Crandell, O.N. 2006, Macroscopic and microscopic analysis of chert: A proposal for standardisation of methodology and terminology. Buletinul Cercurilor Științifice Studențești, 12: 7-30.

Crandell, O.N. 2008, Regarding the procurement of lithic materials at the Neolithic site at Limba (Alba county, Romania): Sources of local and imported materials. In: Geoarchaeology and archaeomineralogy. Proceedings of the International Conference, 29-30 October 2008 Sofia. (Kostov, R.I., Gaydarska, B.I. \& Gurova, M., Eds.). Publishing House "St. Ivan Rilski”, Sofia: p. 36-45. URL: http://mgu.bg/geoarchmin/naterials/06Crandell.pdf 
Crandell, O.N. 2009, Romanian Lithotheque Project: Knappable stone resources in the Mureș Valley, Romania. Studia UBB, Geologia, Special Issue, MAEGS - 16: 79-80.

URL: http://www.studia.ubbcluj.ro/arhiva/abstract_en.php?editie=GEOLOGIA\&nr=Sp ecial\%20Issue\&an=2009\&id_art=7388

Crandell, O.N. 2012a, Lithic sources available to prehistoric populations in the Banat region, Romania. In: Interdisciplinary research in archaeology. Proceedings of the First Arheoinvest Congress, 10-11 June 2011, Iași, Romania (Cotiugă, V. \& Caliniuc, S., Eds.), B.A.R. International Series Vol. 2433. Archaeopress, Oxford: p. 69-78.

Crandell, O.N. 2012b, Petrographic analysis of lithic artefacts from Limba (Romania) to confirm Neolithic trade patterns. Acta Mineralogica-Petrographica, Szeged, 7: 31.

Crandell, O.N. 2014, Knappable materials in the Criș Valley, Romania. Journal of Lithic Studies, 1(2): 47-62. doi:10.2218/jls.v1i2.1101

Crnobrnja, A.N. 2011, Arrangement of Vinča culture figurines: A study of social structure and organisation. Documenta Praehistorica, 38: 131. doi:10.4312/dp.38.11

De Benedetto, G.E., Laviano, R., Sabbatini, L. \& Zambonin, P.G. 2002, Infrared spectroscopy in the mineralogical characterization of ancient pottery. Journal of Cultural Heritage, 3(3): 177-186. doi:10.1016/S1296-2074(02)01178-0

Dunham, R.J. 1962, Classification of carbonate rocks according to depositional structure. In: Classification of carbonate rocks (Ham, W.E., Ed.), Memoir - American Association of Petroleum Geologists Vol. 1. American Association of Petroleum Geologists, Tulsa: p. 108-121.

Fabbri, B., Gualtieri, S. \& Shoval, S. 2014, The presence of calcite in archeological ceramics. Journal of the European Ceramic Society, 34(7): 1899-1911. doi:10.1016/j.jeurceramsoc.2014.01.007

Giușcă, D., Bleahu, M., Lupu, M., Borcoș, M., Dimian, M., Lupu, D. \& Dimitrescu, R. 1967, Geological map of Romania, scale 1:200,000, Turda Sheet. Geological Institute of Romania, Bucharest. (in Romanian)

Graetsch, H.A. 1994, Structural characteristics of opaline and microcrystalline silica minerals. In: Silica: Physcial behavior, geochemistry, and materials applications (Heaney, P.J., Prewitt, C.T. \& Gibbs, G.V., Eds.), Reviews in Minerology Vol. 29. Mineralogical Society of America, Chantilly, VA: p. 209-232.

Handke, M. \& Mozgawa, W. 1993, Vibrational spectroscopy of the amorphous silicates. Vibrational Spectroscopy, 5(1): 75-84. doi:10.1016/0924-2031(93)87057-z

Herz, N. \& Savu, H. 1974, Plate tectonics history of Romania. Geological Society of America Bulletin, 85(9): 1429-1440. doi:10.1130/0016-7606(1974)85<1429:pthor>2.0.co;2

Hlavay, J., Jonas, K., Elek, S. \& Inczedy, J. 1978, Characterization of the particle size and the crystallinity of certain minerals by IR spectrophotometry and other instrumental methods-II: Investigations on quartz and feldspar. Clays and Clay Minerals, 26(2): 139143. doi:10.1346/CCMN.1978.0260209

Ionescu, C. \& Hoeck, V. 2018, Genesis and composition of siliceous rocks and the relation with their nomenclature. In: Raw materials and lithic artefacts from prehistory to Middle Ages in Europe; International colloquium; Programme and abstracts (Preoteasa, C., Cârciumaru, M., Pelisiak, A. \& Nicola, C.-D., Eds.). Editura „Constantin Matasă”, Piatra Neamț: p. 23-26. URL: https://www.academia.edu/38338040/ 
Ionescu, C.H.V. 2010, Mesozoic ophiolites and granitoids in the Apuseni Mts. RO2 Field trip guide, IMA-2010 Budapest. Acta Mineralogica et Petrographica (Szeged). Field Guide Series, 20: 1-45.

Kieffer, S.W. 1979, Thermodynamics and lattice vibrations of minerals: 2. Vibrational characteristics of silicates. Reviews of Geophysics, 17(1): 20. doi:10.1029/RG017i001p00020

Knauth, L.P. 1994, Petrogenesis of chert. In: Silica: Physcial behavior, geochemistry, and materials applications (Heaney, P.J., Prewitt, C.T. \& Gibbs, G.V., Eds.), Reviews in Mineralogy Vol. 29. Mineralogical Society of America, Chantilly, VA: p. 233-258. URL: http://rimg.geoscienceworld.org/content/29/1/233.short

Luedtke, B.E. 1992, An archaeologist's guide to chert and flint: A handbook. Archaeological research tools Vol. 7. Institute of Archaeology, University of California, Los Angeles, $172 \mathrm{p}$.

Madejová, J. 2003, FTIR techniques in clay mineral studies. Vibrational Spectroscopy, 31(1): 1-10. doi:10.1016/s0924-2031(02)00065-6

Mangado, J. 2006, El aprovisionamiento en materias primas líticas: Hacia una caracterización paleocultural de los comportamientos paleoeconómicos. Trabajos de Prehistoria, 63(2). (in Spanish) ("The procurement of lithic raw materials: towards a paleocultural characterisation of palaeoeconomic behaviour") doi:10.3989/tp.2006.v63.i2.18

Moenke, H.H.W. 1974, Silica, the three-dimensional silicates, borates and beryllium silicates. In: The infrared spectra of minerals (Farmer, V.C., Ed.), Monograph Vol. 4. Mineralogical Society of London, London: p. 365-382.

Munsell, A. 1975, Munsell soil color charts. Munsell Colour, Macbeth Division of Kollmorgen Corporation, Baltimore, 30 p.

Nandris, J.G. 1990, Practical and theoretical considerations in highland zone exploitation from ethnoarchaeological fieldwork in southeast Europe. In: The Neolithisation of the Alpine region (Biagi, P., Ed.), Monografie di Natura Bresciana Vol. 13, Museo Civico di Scienze Naturali di Brescia, Brescia: p. 235-235.

Nicolae, I., Soroiu, M. \& Bonhomme, G.M. 1992, Ages K-Ar de quelques ophiolites des Monts Apuseni du sud (Roumanie) et leur signification géologique. Géologie Alpine, 68: 77-83. (in French) ("K-Ar ages of some ophiolites from the southern Apuseni Mountains (Romania) and their geological significance")

Přichystal, A. (2010). Classification of lithic raw materials used for prehistoric chipped artefacts in general and siliceous sediments (silicites) in particular: The Czech proposal. presented at the Archeometriai Mühely, 2010.

Rey-Solé, M. 2016, Determinación arqueopetrológica y territorial de los materiales silíceos entre el sur de Tarragona y el norte de Castellón. Ph.D. thesis at the Faculty of Geography and History, University of Barcelona, Barcelona, 510 p. (in Spanish) ("Archaeopetrologic and territorial determination of siliceous materials among south of Tarragona and north of Castelló”) URL: http://hdl.handle.net/2445/108425 
Rey-Solé, M., Ionescu, C., Ciută, M.M., Mureșan-Pop, M. \& Simon, V. 2018, Archaeometric investigation on Neolithic siliceous tools from Limba-Oarda de Jos (Alba county, Romania). In: Raw materials and lithic artefacts from prehistory to Middle Ages in Europe; International colloquium; Programme and abstracts (Preoteasa, C., Cârciumaru, M., Pelisiak, A. \& Nicola, C.-D., Eds.). Editura „Constantin Matasă”, Piatra-Neamț: p. 47-50. URL: https://www.academia.edu/38338040/

Săndulescu, M.I.V. 1984, Geotectonica României. Editura Tehnică, Bucharest, 336 p. (in Romanian) ("Geotectonics of Romania")

Săsăran, E. 2006, Calcarele jurasicului superior-cretacicului inferior din Munţii Trascău. Presa Universitară Clujeană, Cluj-Napoca, 249 p. (in Romanian) ("The Upper JurassicLower Cretaceous limestones of the Trascău Mts.")

Shoval, S. 2003, Using FT-IR spectroscopy for study of calcareous ancient ceramics. Optical Materials, 24(1-2): 117-122. doi:10.1016/s0925-3467(03)00114-9

Starnini, E., Szakmány, G., Józsa, S., Kasztovszky, Z., Szilágyi, V., Maróti, B., Voytek, B. \& Horváth, F. 2015, Lithics from the Tell site Hódmezővásáehely-Gorzsa (Southeast Hungary): Typology, technology, use and raw material strategies during the Late Neolithic (Tisza culture). Archaäologie in Eurasien, 31: 105-129.

Suciu, C.I. 2009, Cultura Vinča în Transilvania. Bibliotheca Brukenthal Vol. 44. Editura Altip, Alba Iulia, 305 p. (in Romanian) ("Vinča culture in Transylvania")

Suciu, C.I. 2010, Early Vinča culture dynamic in south-easthern Transylvania. In: The lower Danube in prehistory: Landscape changes and human-environment interactions. Proceedings of the International Conference, Alexandria, 3-5 November 2010 (Mills, S. \& Mirea, P., Eds.). Renaissance, Bucharest: p. 75-85.

Tarriño Vinagre, A. 1998, Rocas silíceas sedimentarias: Su composición mineralógica y terminología. Krei, 3: 143-161. (in Spanish) ("Sedimentary siliceous rocks: mineralogic composition and terminology")

URL: https://dialnet.unirioja.es/servlet/articulo?codigo=2733229

Tarriño Vinagre, A. 2006, El sílex en la Cuenca Vasco-Cantábrica y Pirineo navarro: Caracterización y su aprovechamiento en la prehistoria. Monografía Vol. 21. Museo y Centro de Investigación de Altamira, Ministerio de Cultura, Madrid, 263 p. (in Spanish) ("Flint in Basque-Cantabrian basin and Navarrese Pyrenees: Characterization and its use in prehistory")

Whittle, A., Bayliss, A., Barclay, A., Gaydarska, B., Bánffy, E., Borić, D., Draşovean, F., Jakucs, J., Marić, M., Orton, D., Pantović, I., Schier, W., Tasić, N. \& vander Linden, M. 2016, A Vinča potscape: Formal chronological models for the use and development of Vinča ceramics in south-east Europe. Documenta Praehistorica, 43: 1-60. doi:10.4312/dp.43.1 